\title{
HAZARDOUS ENTERPRISES AND RISK BEARING CAPACITY*
}

\author{
GLARENGE MORRIS户े
}

THIs little article deals with what the pedants call "liability for an escaping inanimate destructive force." It is divided into two parts: a sketch of the doctrinal history, and a critical glance at policies underlying present doctrines in the light of some observations on risk bearing capacity.

\section{Doctrinal Development}

In the early English common law there was much support for the proposition that an actor was responsible, without proof of fault, for harm done by his activity. ${ }^{1}$ By the Eighteenth Century, however, English law had changed for most injuries other than defamation and some kinds of damage to real property. Fault had become a prerequisite to liability for personal injury and for damage to personal property.

In mid-Nineteenth Century the important case of Rylands $v$. Fletcher ${ }^{2}$ was decided. A mill owner ordered construction of a dam to get water power. The resulting reservoir lay over ancient abandoned coal mines. The mill owner had no reason to suspect that these old diggings led into an operating colliery, but they did. When the dam was closed, water ran down the old shafts, seeping into and flooding the colliery. The case had an extended history and many opinions were written as it went through the English courts. Ultimately the mill owner was held liable. Two of the opinions are more frequently quoted than the others:

In the Court of Exchequer Chamber Mr. Justice Blackburn said, "[T]he true rule of law is, that the person who for his own purposes brings on his lands and collects and keeps there anything likely to do mischief if it escapes, must keep it in at his peril. ..."3 This view of strict liability was not surprising in a jurisdiction in which courts were committed to the proposition that

\footnotetext{
*This article is an adapted excerpt from a student text on Torts which the writer is preparing.

$\dagger$ Professor of Law, University of Texas Law School; currently Visiting Professor, University of Pennsylvania Law School.

1. In the famous case of the Thorns, Y.B. 6 Ed. IV, f. 7, pl. 18 (1466), the court said: "[T]hough a man doth a lawful thing, yet if any damage do thereby befall another, he shall answer for it, if he could have avoided it." The words "could have avoided it" do not mean "would have avoided it by use of due care," for the court held the defendant liable without fault for accidentally dropping hedge clippings on a neighbor's land. The court expressed similar ideas on other types of accidental injury, including unintended non-negligent personal injuries.

2. 3 H. \& C. 774, 159 Eng. Rep. 737 (Ex. 1865), rev'd, L.R. 1 Ex. 265 (1866), aff'd, L.R. 3 H.L. 330 (1868).

3. Rylands v. Fletcher, L.R. 1 Ex. 265, 279 (1866).
} 
unauthorized entries on land entailed liability without fault in trespass actions. But Blackburn's language was broad enough to cover liability for damages to personal property and injuries to life and limb-even in cases where the harm occurs without an entry on the claimant's real property.

In the House of Lords, Lord Cairns wrote the most influential opinion." He substantially agreed with Blackburn but restricted the rule of liability-without-fault to "non-natural users." He then classified the mill owner's use as non-natural and voted for liability. By "non-natural user" Cairns probably did not mean "artificial user." But he did not define the term. Perhaps he intended to distinguish between traditional use and novel use.

Some American courts purport to follow Rylands $v$. Flctcher, often applying Blackburn's statement of the rule. ${ }^{6}$ Many other American courts have attempted total rejection of the Rylands holding. One of the early leading cases was Marshall $v$. Welwood and Garside, ${ }^{7}$ a suit for property damages resulting from a bursting steam boiler. The trial judge charged the jury that the boiler-owner could be found liable without proof of fault. The appellate court viewed Rylands $v$. Fletcher as an anomaly in a law of torts in which most liabilities depend on fault. Comparing the case before it to a traffic accident the court said,

"[I]f traffic cannot be carried on without some risk, why can it not be said with the same truth, that other affairs of life, though they be transacted away from highways, cannot be carried on without some risk; and if such risk is, in the one case, to be borne by innocent persons, why not in the other?'s

But the idea that enterprisers should pay for all damages resulting from their undertaking has strong appeal, especially when even careful prosecu-

4. Rylands v. Fletcher, L.R. 3 H.L. 330, 337-40 (1\&68).

5. The English courts developed another important limitation by holding that legislative permission to conduct an activity has the same effect as "natural user." In Northwestern Util., Ltd. v. London Guarantee \& Acc. Co., [1936] A.C. 10 S (P.C. 1935), the rule of Rylands $v$. Fletcher was held inapplicable to a utility company whose gas eseaped into a basement and exploded-because the company located and used its pipes in ascordance with statutory permission.

6. His recognition of act of God as a defense has also been followed. In a Minnesota case a city whose storm sewers overflowed in an unprecedented rain storm escaped liability on this ground. Power v. City of Hibbing, 1S2 MIinn. 66, 233 N.W. 597 (1930). Cairns' limitation to non-natural user has been honored from time to time. In IIcCord Rubber Co. v. St. Joseph Water Co., 181 Mo. 678, 81 S.W. 189 (1904), an action for damage to goods in a cellar resulting from bursting water mains through which a water company supplied its customers, the court held that the water was "brought in by the method universally in use in cities and is not to be treated as an unnatural gathering of a dangerous agent." Id. at 695, 81 S.W. at 193 (1904).

7. 38 N.J.L. 339 (1876).

8. Id. at 345. Other well-known sweeping repudiations of $K y$ lands $:$ Flctcher are Lasee v. Buchanan, 51 N.Y. 476 (1876); Turner v. Big Lake Oil Co., 123 Tex. 155, 96 S.W.2d 221 (1936). 
tion of an enterprise conducted for profit is freighted with risk. This appeal is heightened when the enterprise is novel.

Sometimes courts discuss the problem of enterprise liability in terms of a special type of activity. Blasting is a good example. Some American courts hold a blaster liable for proximately consequent harms to persons and property without proof of fault and even though use of explosives in performing an important service is necessary and justifiable. ${ }^{\circ}$ Other specific kinds of enterprise have received legislative attention. For example, the Uniform Aeronautics Act, adopted in several states, provides that the operator of falling aircraft is responsible for resulting damage without proof of fault.

The focus on blasting and falling aircraft in current opinions is, of course, much narrower than the judicial focus in Rylands v. Fletcher. Blackburn and Cairns tried to generalize on all cases in which gathered substances escape and do damage. Some courts have taken a position somewhere between these two extremes; their focus has been on extra-hazardous activities. In Exner v. Sherman Power Construction C0., ${ }^{10}$ a contractor stored dynamite at the site of a large construction job; it exploded, damaged a nearby house, and injured the householder. The court said that blasting had been singled out as a type of activity entailing liability without fault, and that there was no reason to distinguish between (1) intentional blasting explosions and (2) accidental explosions of dynamite stored where it could do harm. Then the court generalized still further:

"When a person engages in such a dangerous activity, useful though it may be, he becomes an insurer.

". . . When, as here, the defendant, though without fault, has engaged in the perilous activity of storing large quantities of a dangerous explosive for use in his business, we think there is no justification for relieving it of liability, and that the owner of the business, rather than a third person who has no relation to the explosion, other than of injury, should bear the loss."11

Using this rationale, other courts have visited liability without proof of fault on enterprises engaged in a wide variety of ultra-hazardous activities. ${ }^{12}$

9. See, e.g., Federoff v. Harrison Construction Co., 362 Pa. 181, 66 A.2d 817 (1950). Other courts refuse to distinguish between blasting and less hazardous enterprises and hold a blaster is not liable for any type of harm unless blasting was unjustifiable or improperly done. See, e.g., Stanolind Oil \& Gas Co. v. Lambert, 222 S.W.2d 125 (Tes. Civ. App. 1949). Still other courts have worked out an intermediate position by use of a trespass q.c.f. analysis; if a blast throws damaging rocks or debris on adjoining property the blast is denominated an unauthorized entry and the blaster is held liable, but if the damages are done merely by concussion or vibration they are not held sufficiently "dircet" to constitute a trespass, and therefore the blaster is not liable unless his fault is established. See, e.g., Booth v. Rome, W. \& O.T.R.R., 140 N.Y. 267, 35 N.E. 592 (1893).

10. 54 F.2d 510 (2d Cir. 1931).

11. Id. at 514.

12. In Green v. General Petroleum Corp., 205 Cal. 328, 270 Pac. 952 (1928), an oil producer's careful drilling nevertheless resulted in a "blow out" which threw oil, mud, 


\section{Policy Analysis of Enterprise Liability Without Fault}

Long before Rylands $v$. Fletchcr the trespass rule of strict liability for unauthorized entries had been enshrined as good English common law. When $R y l a n d s$ was tried in Exchequer, Bramwell, B. termed the flow of water into the mine a trespassory entry. Martin, $B$. was unwilling to accede; he said that the mine damage was "too consequential" to constitute a trespass. For over a century and a half English tort law had been moving away from strict liability for acts and while Martin did not repudiate the unauthorized entry rule, he showed a distinct distaste for liability without fault.13 The Chief Baron, Pollock, voted with Martin, and the miner's claim was disallowed at trial. Martin's views were surely known to the judges in Exchequer Chamber and the House of Lords when they held the mill operator liable. It seems most unlikely that all of the appellate judges were concerned only with technical aspects of trespass doctrine. What considerations did lead to the rejeetion of Martin's views?

It has been suggested that most of the judges were recruited from the gentry, a class which frowned on the industrial invasion of the stately English countryside. Mills were no longer picturesque grinders of home-grown grain for kitchen-baked bread; they were unsightly, ungainly, "non-natural" textile factories run by men "in trade." They should at least pay their way-which included paying for damage done to neighbors. Even though such a policy might result in one industrialist paying off another (as it did in Rylands $v$. Fletcher), it would also shield rural souls who found themselves near burgeoning industry.

American judges of the Nineteenth Century were of a different breed. MIany were politicians; all were living in a new land crying for exploitation; indus-

sand, and rocks on nearby property. The court held the producer liable on the ground that he acted with lnowledge that injury might result to his neightor. More recently, in Luthringer v. Moore, S0 A. Cal. App. 123, 181 P.2d \$9 (3d Dist. 1947), aff'd. 31 C31. 2.1 489,190 P.2d 1 (1948), an exterminator used hydrocyanic gas to rid a restaurant di cockroaches and poisoned a workman in an adjoining store. The trial judge charged the jury that the exterminator a'as liable without proof of fault. The appellate caurts aftirmed on the ground that the enterprise was ultra-hazardous, and therefore the enterpriser was liable for foreseeable injuries proximately resulting from reasonably careful prosecution of the enterprise. Said the Court of Appeals, "[T]he dangerous enterprise must "pay its way' and the tendency of the courts is to impose liability for resulting injuries which are foreseeable within the risk created." Luthringer v. Moore, 80 A. Cal. App. 123, 132, 181 P.2d 89, 96 (3d Dist. 1947). The Supreme Court agreed.

13. He said, "To hold the defendants liable would ... make them insurers against the consequence of a lawful act upon their own land when they had no reason to talieve or suspect that any damage was likely to ensue.

“... [T] here is no better established rule of law than that when damage is done to personal property, and even to the person, by collision either upon the read or at sea, there must be negligence in the party doing the damage to render him legally respunsible. ... I can see no reason why damage to real property shuuld be governed by a different rule or principle than damage to personal property." Kylands r. Fletcher, 3 H. \& C. 774, 793, 159 Eng. Rep. 737, 745 (Ex. 1865). 
trialists were often dominant figures in society; country gentlemen were rarely judges in industrial states. Most of the American judges lacked incentive to buck the persistent drift away from liability without fault. Perhaps this difference in background accounts for the inhospitality to Rylands $z^{\prime}$. Fletcher in many states. But such is the power of "authority" that several states nevertheless embraced the views of Blackburn and Cairns.

The industrialization of both England and America is now an accomplished fact; forces that moulded Nineteenth Century law are spent or changed. The current virility of the demand for (and opposition to) enterprise liability without fault thus requires a different kind of rationale. Scholarly proponents (whose ideas are reflected in some legislation and an occasional judicial opinion) applaud liability without fault as a method for imposing losses on superior risk bearers. Their argument usually runs this way: One who should know that his activity, even though carefully prosecuted, may harm others, should treat this harm as a cost of his activity. If the activity is a business enterprise, this cost item will influence pricing and will be passed on to consumers, spread so thin that no one will be seriously affected. If the activity is not a business enterprise, the actor should not prosecute it for his own purpose unless he is willing to pay the price. Actors can normally control this cost item by getting liability insurance, which substitutes a fixed premium for the hazard of ruinous runs of bad luck. The economics of this argument is, as we shall see, built on dubious assumptions and oversimplifications, but the theory is a rough approximation of what actually happens in some situations. Workmen's Compensation Laws, adopted in some form by virtually all state legislatures, are a good example. The compensation claimant is usually a poor risk bearer whereas industry generally is able to shift to consumers the cost of workmen's compensation based on liability without fault.

Thus the avowed goal of the absolute liability approach is allocation of loss to the party better equipped to pass it on to the public: the superior risk bearer. At the same time, of course, the total cost of the mishap should be minimized. Hence, if a defendant's superior risk bearing capacity is a good reason for shifting a loss to him, a plaintiff's superior risk bearing capacity provides an even better reason to let the loss lie where it has fallen, for the administrative and legal expenses of shifting the loss may be saved. The policy, then, should be one of transferring losses only when necessary to achieve the overriding goal of proper loss allocation-when, in other words, the shift is from an inferior to a superior risk bearer. Clearly, the fault principle's disregard for risk bearing capacity renders it inappropriate for achieving this policy. Yet in the field of hazardous enterprise, an absolute liability rule would also defeat this policy if the rule's underlying assumption-that defendant is always the better risk bearer-were in fact erroneous.

No one has suggested that the courts hear proof in each case on the risk bearing capacity of the particular litigants. Proof of the affluence or poverty of litigants is usually excluded as irrelevant and prejudicial (though, of course, jurors and judges may consciously or unconsciously be influenced by 
their suppositions on these subjects). If such issues were contested, trials would be long and costly and often beyond the competence of judge and jury. Moreover, our sense of justice is outraged when claimants are favored merely because they happen to be poor and defendants are disfavored merely bccause they happen to be rich.

We are not so shocked, however, when courts or legislatures deal with the classes of persons to which individual litigants belong-for example, injured workmen, landowners who seize cattle damage feasant, blasters, or those engaged in extra-hazardous businesses. Though liability without fault of classes of defendants to classes of plaintiffs has drawn criticism, it seldom evokes widespread indignation.

What classes of litigants are superior or inferior risk bearers? Mr. Enterpriser is a construction contractor who is readying a bid on a highway bridge that cannot be feasibly built without blasting near houses and people. Even if Enterpriser is not liable for blasting damages without proof of fault, he will be foolish to make his bid without taking into account the cost of liability insurance-for if someone is injured the likelihood is fairly high that Enterpriser or his servants will be proved negligent to a court's satisfaction. And, of course, liability without fault will increase Enterpriser's risl, forcing him to utilize insurance despite even higher rates. Only financially irresponsible contractors will venture to disregard this cost and, for a number of reasons, they are not likely to win the bidding. Since, therefore, the cost of liability is calculated in fixing Enterpriser's price, Enterpriser is a good risk bearer.

Enterpriser is the successful bidder. He commences work and blasts carefully but nevertheless decimates the nearby chicken flock of MIr. Neighbor. Since chicken raisers as a class are not likely to be injured by blasting and Neighbor must meet his competitors' prices, he cannot recoup his losses by boosting his prices for chickens and eggs. Of course all poultry production is threatened to some extent by other catastrophic risks such as epidemic disease, lightning, and tornado. These uncertainties may discourage those who would otherwise become chicken raisers and thus affect prices slightly, but when the heavy hand of disaster falls on a chicken farm, the farmer may well face bankruptcy. Enterpriser is not only a good risk bearer; he is a better risk bearer than Neighbor.

If Neighbor's injuries were to his body, the conclusion would be much the same. The financial burden of disabling personal injury overwhelms most people. While many can bear the cost of minor injury, prolonged infirmity and extended medical expense often exceed the financial competence of common men. Unless Neighbor happens to be rich or covered by one of the more generous workmen's compensation plans, he will probably bear the risk: less easily than Enterpriser. The preponderant likelihood is that Enterpriser is the better risk bearer of the two.

Supose the harm to Neighbor is damage to his improved urban property-the roof is knocked off his warehouse. Nearly all city buildings are nuw 
insured against fire, and most policies carry "extended coverage" endorsements insuring against hazards other than fire, including damage resulting from ex"plosion. After Neighbor is compensated by his insurance company, it will be subrogated to his rights; liability without fault will result in a shift of loss from the fire insurance company to Enterpriser, transferred in turn to Enterpriser's liability insurer. Although both Neighbor and Enterpriser are insured, Neighbor is actually the superior risk bearer; property insurance is a better risk distributing device than liability insurance for two reasons.

First, a property owner can determine how much insurance he needs and can buy the right amount; a contractor insuring against liability never knows how much he may need. If Neighbor owns a $\$ 40,000$ warehouse, he can come close to discerning its value and will probably buy $\$ 40,000$ worth of insurance. Enterpriser must guess at the damage he may cause. If his guess is too low, he becomes a self-insurer for damage in excess of his limits and is likely to be a poor risk bearer for these damages. If his guess is exaggerated, his pricing will be too high or he will himself bear a wasteful burden.

Secondly, from the claimant's standpoint, property losses are adjusted more favorably (on the average) than liability losses. Neighbor's fire policy provides for settlement of claims in various ways. For example, if he and his insurer disagree on the actual cash value of the property destroyed, the insurer can rebuild; or if the loss is total and the policy is "valued," liquidated damages have been set in advance. And Neighbor's insurance company, enger to hold the good will of its customers, has special incentives for dealing with them promptly and justly. But Neighbor is not a customer of Enterpriser's liability insurer; settlement of a liability claim is much more likely to result iu dickering, delay, and possibly litigation. This is often true even when a property insurer is subrogated to a claim and asserts it against a liability insurer.

In the warehouse case Neighbor is the superior risk bearer. But suppose that Enterpriser, instead of building a bridge, establishes a nitroglycerin factory near Neighbor's warehouse. The proximity of this hazard may make the warehouse uninsurable; no insurance company following sound underwriting principles would keep such a risk at regular rates, if at all. For similar reasons Enterpriser will probably have difficulties in securing liability insurance; but he still has the alternative of setting up reserves, becoming a self-insurer, and charging this expense to his customers. Neighbor, too, can become a self-insurer but he will be unable to pass on costs to his customers and remain a successful competitor. Who would pay more than the usual storage charges for the doubtful privilege of storing goods next to a nitroglycerin plant? Enterpriser is probably the better risk bearer in this case.

Thus far, discussion has centered on hazards that are regularly a part of Enterpriser's business. But sometimes a justifiably risky activity is sporadic or occasional and neither affects pricing nor is covered by insurance-a householder undertakes to cut a decayed tree close to a heavily traveled street, a small resort owner blasts while building a private road, etc. These engagers 
in hazardous activity are not likely to be good risk bearers; they do not have opportunities to pass their losses on to consumers and probably have no plans for bearing them.

\section{Conclusion}

The conclusion reached is that those engaged in dangerous activities sometimes are and sometimes are not better risk bearers than those injured by the prosecution of the activities. The system of analysis used is based on speculation and assumption, but no more scientific materials are now available to justify some of the other schemes proposed and actually adopted in this field. The discussion does justify the conclusion that a general rule of absolute enterprise liability or liability for hazardous undertakings is bound to saddle some kind of defendants with losses they can bear no better than the linds of plaintiffs compensated. Only courts discriminating wisely among classes of cases that are now lumped together can evolve a system in which losses are shifted only from classes of inferior risk bearers to classes of superior risk bearers. The necessary discriminations collide with some traditional notions of evenhanded justice, notions which are not likely to fade easily or quiclily. And the function of making these discriminations will not be adequately performed except by a judiciary trained to weigh economic facts and informed by experts who know much about the economics of accident loss. But perhaps progress toward a more sensible allocation of accident losses cannot wait for better knowledge on which to build an ideal system. Possibly an ad hoc development of enterprise liability can serve us better than either a system of absolute liability or one in which liability is tied to fault. 